\title{
A 30-meter terrace mapping in China using Landsat 8 imagery and digital elevation model based on the Google Earth Engine
}

Bowen $\mathrm{Cao}^{1}$, Le $\mathrm{Yu}^{1,2, *}$, Victoria $\mathrm{Naipa}^{3}$, Philippe Ciais ${ }^{4}$, Wei $\mathrm{Li}^{1,2}$, Yuanyuan Zhao ${ }^{5,6}$, Wei Wei ${ }^{7}$, Die 5 Chen $^{7}$, Zhuang Liu ${ }^{1}$, Peng Gong ${ }^{1,2}$

${ }^{1}$ Ministry of Education Key Laboratory for Earth System Modeling, Department of Earth System Science, Tsinghua University, Beijing 100084, China;

${ }^{2}$ Ministry of Education Ecological Field Station for East Asian Migratory Birds, Beijing 100084, China;

${ }^{3}$ Department of Geography, Ludwig-Maximilian University, Munich, Germany;

$10{ }^{4}$ Laboratoire des Sciences du Climat et de l'Environnement, CEA-CNRS-UVSQ, UMR8212, Gif-sur-Yvette, France; ${ }^{5}$ College of Land Science and Technology, China Agricultural University, Beijing 100083, China;

${ }^{6}$ Key Laboratory of Remote Sensing for Agri-Hazards, Ministry of Agriculture and Rural Affairs, Beijing 100083, China; ${ }^{7}$ State Key Laboratory of Urban and Regional Ecology, Research Center for Eco-environmental Sciences, Chinese Academy of Sciences, Beijing 100085, China

15 Correspondence to: Le Yu (leyu@tsinghua.edu.cn) 
Table S1: Explanation of variables in Fig. 10 of Section 3.5.

\begin{tabular}{|c|c|}
\hline Variable & Explanation \\
\hline Blue_25th & The 25th percentile of surface reflectance of Blue band. \\
\hline Blue_50th & The 50th percentile of surface reflectance of Blue band. \\
\hline Blue_75th & The 75th percentile of surface reflectance of Blue band. \\
\hline Green_25th & The 25 th percentile of surface reflectance of Green band. \\
\hline Green_50th & The 50th percentile of surface reflectance of Green band. \\
\hline Green_75th & The 75th percentile of surface reflectance of Green band. \\
\hline Red_25th & The 25th percentile of surface reflectance of Red band. \\
\hline Red_50th & The 50th percentile of surface reflectance of Red band. \\
\hline Red_75th & The 75th percentile of surface reflectance of Red band. \\
\hline NIR_25th & The 25th percentile of surface reflectance of NIR band. \\
\hline NIR_50th & The 50th percentile of surface reflectance of NIR band. \\
\hline NIR_75th & The 75th percentile of surface reflectance of NIR band. \\
\hline SWIR1_25th & The 25 th percentile of surface reflectance of SWIR 1 band. \\
\hline SWIR1_50th & The 50th percentile of surface reflectance of SWIR 1 band. \\
\hline SWIR1_75th & The 75 th percentile of surface reflectance of SWIR 1 band. \\
\hline SWIR2_25th & The 25 th percentile of surface reflectance of SWIR 2 band. \\
\hline SWIR2_50th & The 50th percentile of surface reflectance of SWIR2 band. \\
\hline SWIR2_75th & The 75th percentile of surface reflectance of SWIR2 band. \\
\hline TIRS2_25th & The 25th percentile of surface reflectance of TIRS 2 band. \\
\hline TIRS2_50th & The 50th percentile of surface reflectance of TIRS 2 band. \\
\hline TIRS2_75th & The 75th percentile of surface reflectance of TIRS 2 band. \\
\hline NDVI_p25 & The 25th percentile of Normalized Difference Vegetation Index. \\
\hline NDVI_p50 & The 50th percentile of Normalized Difference Vegetation Index. \\
\hline NDVI_p75 & The 75th percentile of Normalized Difference Vegetation Index. \\
\hline MNDWI_p25 & The 25th percentile of Modified Normalized Difference Water Index. \\
\hline MNDWI_p50 & The 50th percentile of Modified Normalized Difference Water Index. \\
\hline MNDWI_p75 & The 75th percentile of Modified Normalized Difference Water Index. \\
\hline NDBI_p25 & The 25th percentile of Normalized Difference Building Index. \\
\hline NDBI_p50 & The 50th percentile of Normalized Difference Building Index. \\
\hline NDBI_p75 & The 75th percentile of Normalized Difference Building Index. \\
\hline BSI_p25 & The 25th percentile of Bold Soil Index. \\
\hline BSI_p50 & The 50th percentile of Bold Soil Index. \\
\hline BSI_p75 & The 75th percentile of Bold Soil Index. \\
\hline Elevation & Elevation. \\
\hline Slope & Slope. \\
\hline SOS & Slope of slope. \\
\hline $\mathrm{R}$ & Roughness. \\
\hline $\mathrm{P}$ & Slope shape. \\
\hline RF & Relief. \\
\hline
\end{tabular}


20 Table S2: Detailed information of data used in this study.

\begin{tabular}{|c|c|c|c|c|}
\hline Title & $\begin{array}{l}\text { USGS Landsat } 8 \text { Surface } \\
\text { Reflectance Tier } 1\end{array}$ & $\begin{array}{l}\text { NASA SRTM Digital } \\
\text { Elevation } 30 \mathrm{~m}\end{array}$ & GlobeLand30 & I \\
\hline Acquisition time & 2018 & 2000 & 2010 & $\begin{array}{l}\text { Most images were } \\
\text { accessed in 2018-2019 }\end{array}$ \\
\hline Description & $\begin{array}{l}\text { This dataset is the surface } \\
\text { reflectance from the } \\
\text { Landsat } 8 \text { OLI/TIRS } \\
\text { sensors. It has been } \\
\text { atmospherically corrected } \\
\text { and includes a cloud, } \\
\text { shadow, water, and snow } \\
\text { mask, as well as a per-pixel } \\
\text { saturation mask. }\end{array}$ & $\begin{array}{l}\text { This dataset is an } \\
\text { international research } \\
\text { effort that obtained DEM } \\
\text { on a near-global scale. It } \\
\text { has undergone a void- } \\
\text { filling process using open- } \\
\text { source data (ASTER } \\
\text { GDEM2, GMTED2010, } \\
\text { and NED). }\end{array}$ & $\begin{array}{l}\text { This dataset is a } 30 \text {-meter } \\
\text { resolution global land } \\
\text { cover data product. It is } \\
\text { generated by integration of } \\
\text { pixel-based and objected- } \\
\text { based methods with } \\
\text { knowledge (POK) using } \\
\text { multi-source data. }\end{array}$ & $\begin{array}{l}\text { This dataset is a } \\
\text { composited product } \\
\text { combining multiple sets of } \\
\text { satellite imagery. The } \\
\text { satellite images are } \\
\text { provided by different } \\
\text { commercial image } \\
\text { providers or government } \\
\text { agencies at different zoom } \\
\text { level. }\end{array}$ \\
\hline Image sources & / & l & l & $\begin{array}{l}\text { CNES / Airbus, Maxar } \\
\text { Technologies, Landsat / } \\
\text { Copernicus }\end{array}$ \\
\hline
\end{tabular}

